\title{
社区生活圈中公服设施供需评估研究——上海市宜川路街道 为例
}

张雅琪

长江大学

DOI:10.32629/btr.v3i8.3328

\begin{abstract}
[摘 要] 近年来国内不乏关于居住区公共服务设施配套不足、公共生活遗乏等问题的讨论。从生活 圈的角度对公服设施评估, 既能摸底城市公共服务现状, 回应居民关心的生活便利度问题, 也能为后续 城市公共服务建设管理提供决策依据。本文选取上海市普陀区宜川路街道为研究区域, 研究15分钟生 活圈内公共服务设施的服务水平以及布局的合理性,为设施的配套完善、社区生活品质的提升提供一 定的依据。
\end{abstract}

[关键词] 15分钟社区生活圈；公服设施；宜川路街道

中图分类号：G811 文献标识码：A

\section{1 国内外研究背景}

在 20 世纪 50 \% 60 年代, 为了解决城市 化过程中出现的各种城市问题, 日本政 府提出了 “广域生活圈” 的概念, 主张在 全面都市化的过程中, 加强中心城市治 理、交通体系建设及开发项目再配置, 形成城市化的日常生活圈 ${ }^{[1]}$ 。韩国在《全 国国土综合开发计划》中, 依据中心城市 的规模将生活圈区分为大都市生活圈、 地方都市圈与乡村城市生活圈, 分别拟 定开发策略 ${ }^{[2]}$ 。而中国台湾地区也在 1979年的综合开发计划中, 采用“地方生 活圈”的概念对城市进行分等定级, 共计 划分 35 个生活圈 ${ }^{[3]}$ 。近年来, 上海、北 京与成都等城市分别在新一轮城市总体 规划、“十三五” 规划纲要中提出重点打 造15分钟生活圈。其中, 上海市规划和自 然资源局于 2016 年 8 月颁布了《上海市 15 分钟社区生活圈规划导则》, 这也是国内 最早明确提出 “15分钟社区生活圈” 概 念的城市。

\section{2 宜川路街道现状概况}

宜川路街道是上海市普陀区辖下的 街道, 位于普陀区东侧, 紧邻闸北区, 面 积 2.2 平方公里, 下辖 21 个居委会。据 2018年数据统计, 宜川路街道2018年常

宜川街道分年龄户籍的人口数比例金字塔

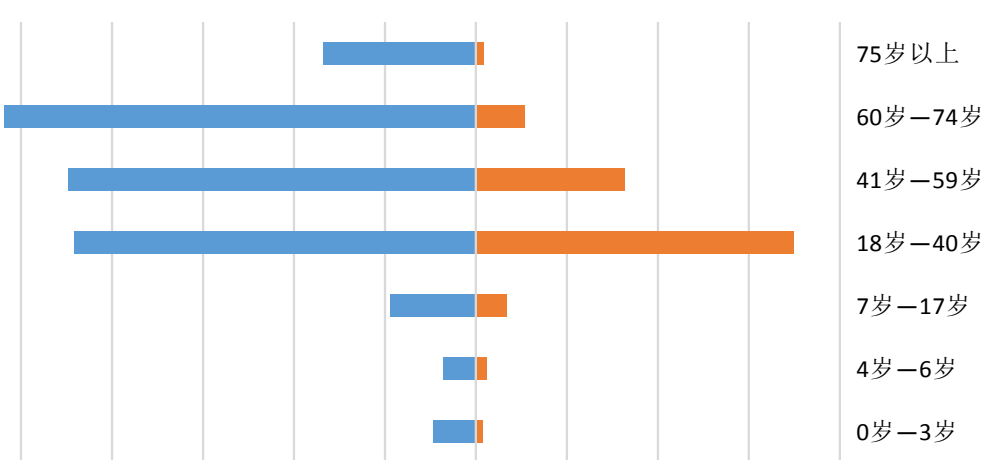

$30000.025000 .020000 .015000 .010000 .05000 .0 \quad 0.0 \quad 5000.0 \quad 10000.015000 .020000 .0$

$$
\text { 非户籍 } \square \text { 户籍 }
$$

住人口总量为 12.08 万人, 占普陀区总人 口的 $8.8 \%$, 在普陀区中处中等偏低水平。 街道现状人口密度较高, 主要集中分布 在街道南部。宜川路街道户籍人口年龄 结构 “头重脚轻”, 老龄化尤为严重, 60 岁以上户籍人口占比达到 $39.2 \%$, 社区进 入重度老龄化阶段。

3 宜川路街道不同类型公服设 施供给需求评估结果

3. 1 基础为老服务设施缺口较大, 且 空间分布不均衡

根据评估结果, 宜川路街道综合为
老服务中心缺口约为 $1892 \mathrm{~m}^{2}$, 日间照料 中心和助餐点缺口约为 $2700 \mathrm{~m}^{2}$, 老年活 动室缺口约为 $1818 \mathrm{~m}^{2}$ 。从社区基础为老 设施的空间布点来看, 宜川路街道北部 片区基础养老设施15分钟范围圈服务水 平高于南部片区, 北部片区服务于常住 老年人口的比例为 $72 \%$, 而南部片区服务 于常住老年人口的比例为 $39 \%$ 。这些服务 盲区未来需要新增养老服务设施。

3. 2 规划幼儿园建成以后, 宜川路街 道托幼设施仍存在部分盲区

目前宜川路街道幼儿园有11所, 托 
儿所有 1 所, 共计 12 所。根据评估, 宜川路 街道托幼设施现状 10 分钟步行服务范围 的社区覆盖率达到 $75 \%$, 可达性一般。规 划幼儿园建成后, 宜川社区养育托管服 务设施的现状 10 分钟步行范围覆盖率达 86\%, 步行可达性良好, 但中远两湾城、佳 景公寓、和丰苑等小区仍存在服务盲区, 建议通过鼓励商业增设养育托管设施来 弥补服务空缺。

3. 3 社区级体育设施服务水平较好, 但场地开放水平不足

宜川路街道现状体育健身点有52处, 片区中心有 1 处, 百姓健身房有 1 处, 学校 体育设施有 8 处, 正在规划建设的光新体 育场也被纳入其中, 共计63处。根据评估, 宜川路街道社区体育健身点设施尚有约 $933 \mathrm{~m}^{2}$ 的缺口。在体育设施的分布上, 体 育健身点 5 分钟服务覆盖率达 $93 \%$, 片区 中心与社区健身房 10 分钟服务覆盖率达 $89 \%$, 光新体育场与学校体育设施 15 分钟 服务覆盖率达 $87 \%$, 步行可达性良好。总 的来说宜川路街道社区级体育设施服务 水平较好, 但场地开放水平不足, 建议考 虑学校运动场馆分时共享。

3. 4 文化设施资源较丰富, 但社区级 文化设施规模不足

宜川路街道现状区级文化服务设施 为普陀区少年儿童图书馆, 共计 1 处。社 区级文化服务设施主要有宜川社区文化 活动中心和片区中心, 共计 2 处。居委级 文化服务设施主要有宜川一村、宜川二
村等居委文化活动室, 共计 23 处。根据相 关数据统计分析, 宜川路街道社区文化 活动中心尚有约 $5176 \mathrm{~m}^{2}$ 缺口。根据社区 文化服务设施可达性评估结果, 宜川路 街道居委级文化活动室5 分钟步行范围 覆盖率达84\%, 步行可达性良好。宜川路 街道社区级文化服务设施的15分钟步行 范围覆盖率达 $75 \%$, 步行可达性一般。宜 川路街道区级文化服务设施的15分钟步 行范围覆盖率达35\%, 步行可达性较低。

3.5 社区医疗服务设施缺口较大, 建 议片区中心建设社区卫生服务站

宜川路街道社区医疗服务设施较少, 社区卫生服务中心尚有约 $2949 \mathrm{~m}^{2}$ 缺口, 社区卫生服务站尚有约 $1218 \mathrm{~m}^{2}$ 缺口。据 可达性评估结果, 宜川路街道社区卫生 服务中心的 15 分钟步行范围覆盖率达 $52 \%$, 步行可达性一般。宜川路街道社区 卫生服务站的 10 分钟步行范围覆盖率达 $48 \%$, 步行可达性较低。宜川路街道铁路 以北社区包括宜川一村、宜川四村、宜 川二村社区均缺乏社区服务站10分钟服 务覆盖。

\section{4 结论与建议}

通过定量分析和评价发现, 宜川路 路街道 “15分钟社区生活圈” 覆盖度中 等, 其中体育设施、社区级文化设施处于 较高水平, 覆盖率都在 $87 \%$ 以上。为老设 施、幼儿园覆盖率中等; 区级文化设施 和医疗设施存在较大的服务盲区, 还有 较高的提升空间。
本研究是基于 “ 15 分钟社区生活 圈” 的理念, 在GIS中进行道路网的构 建和服务区的分析, 从而得到上海市 宜川路街道现状生活圈公服设施的服 务水平。由此可见, 依据人口、现状道 路和公服设施等可靠真实的数据, 可 对城市现状 15 分钟生活圈的便利度进 行量化, 得出现状设施位置与布局的 可视化评价结论, 从而找到社区生活 圈中公共服务配套设施配置不充分、 不均衡的区域, 为后续城市规划的精 准公共服务配套设施布局规划提供依 据。在本研究基础上, 可进一步调研经 济、社会治理等方面的数据, 对社区公 共服务设施进行精细化规划与管理, 提升城市生活便利度。

\section{[参考文献]}

[1]陆书至.日本全国综合开发的产生和 效果[J].地理学与国土研究,1992(1):50-54.

[2]林子瑜.地方生活圈规划与实施问题 之探讨[J].都市与计划,1984(11):175-187.

[3]陈丽瑛.生活圈,都会区与都市体 系[J]. 经济前瞻, 1989(16):127-128.

[4]陈丽䒨.对”国建六年计划” 产业圈与生活圈规划之评议[J]. 经济前 瞻,1991(22):48-51.

\section{作者简介:}

张雅琪(1995--), 女, 汉族, 河南省郑 州市塚阳市人, 在读研究生, 研究方向: 城市规划。 